IKONOMIKA: Jurnal Ekonomi dan Bisnis Islam

Volume 4, No. I (2019)

ISSN : 2527-3434 (PRINT) - ISSN: 2527-5I43 (ONLINE)

Page : I3 - 34

\title{
The Diversity Of Waqf Implementations for Economic Development in Higher Education
}

\author{
Ahmad Shaifull Anuari ${ }^{\mathrm{I}}$, Zakaria Bahari' ${ }^{2}$, Caturida Meiwanto Doktoralina ${ }^{3}$, \\ Fitri Indriawati ${ }^{4}$, Lucky Nugroho ${ }^{5}$ \\ Centre For Islamic Development Management Studies (ISDEV) Universiti Sains Malaysia ${ }^{\mathrm{I}, 2}$, \\ Department of Accounting,Economic \& Business Faculty Universitas Mercu Buana ${ }^{3,4,5}$ \\ shaiful_78@yahoo.com,bzak@usm.my², \\ caturida_meiwanto_drm@mercubuana.ac.id ${ }^{3}$,fitri_indriawati@mercubuana.ac.id ${ }^{4}$, \\ lucky.nugroho@mercubuana.ac.id ${ }^{5}$
}

\begin{abstract}
The development of higher education in Malaysia is multiplying based on the increasing numbers of Public Higher Learning Institutions (IPTA) and Private Higher Learning Institutions (IPTS). This increase has encouraged various parties to collaborate to create a solid foundation and strategy to create IPT to become more competitive. However, the funding factor is still one restraint that IPTs must face. To overcome this problem, one example of IPT is taking the initiative by implementing waqf for higher education in limited institutions. Based on this scenario, the present paper was written to achieve two objectives:The first isto examine the precise development of higher education waqf that has been implemented in IPT in Malaysia. Thesecond isto precisely examine the variety of waqf that can be implemented for higher education. This study is an exploration in which the data used were derived from library research. The findings of this study will develop a theory on the diversification of waqf implementations for higher education in Malaysia.
\end{abstract}

\section{Keywords: Diversity, Economic, Instrument of Waqf, Waqf of Higher Education}

\section{A. INTRODUCTION}

Islam is very concerned about social issues such as poverty, health, and education(Ramadhan \& Al, 20I9; Ruthven, 20I2; Sofyani, Ulum, Syam, \& Wahjuni, 2012). Therefore to overcome these social problems, Islam has a solution using social funds obtained from zakat, infaq, shodaqoh, and waqf. In Islamic education is the main issue, this is reflected in Q.S Al-'Alaq verse I-5: "(I)Recite in the name of your Lord who created ; (2) Created man from a clinging substance; (3) Recite, and your Lord is the most Generous; (4) Who taught by the pen; (5)

Received: March 4, 2019 - Revised: March I6, 2019 - Accepted :March I6, 2019

Centre For Islamic Development Management Studies (ISDEV) Universiti Sains Malaysia ${ }^{1,2}$, Department of Accounting,Economic \& Business Faculty Universitas Mercu Buana ${ }^{3,4,5}$ shaiful_78@yahoo.com,bzak@usm.my²,

E-mail : caturida_meiwanto_drm@mercubuana.ac.id ${ }^{3}$, fitri_indriawati@mercubuana.ac.id lucky.nugroho@mercubuana.ac.id ${ }^{5}$ 
Taught man that which he knew not.' Based on these matters, then studying for a Muslim is an obligation. Of course, to get a quality education requires a fee(Fazial $\&$ Bahari, 2018). Thus, because education in Islam is an obligation, all Muslims are entitled to quality education including those who cannot afford to pay for their education (low-income community).

The development of higher education waqf in Malaysia is interesting to study due to the role of the IPTA and IPTS that have participated. Waqf is an alternative method of funding education and university development. The reason for it is that government funding for educational institutions and universities seeking their development capital also continue to increase.

Meanwhile, Siswantoro \& Dewi, (2007)affirms that the waqfinstitution in Indonesia has not been effective in the handle of a social issue because of two reasons. First, the government does not perceive that the waqffund can be a potential source of income to support high economic growth. Second, most Indonesian people still assume that waqf is only limited in the form of fixed assets. Therefore, the waqf approach in the field of education is a substantial investment that can produce quality human resources, such as practitioners and experts who have high spiritual values. Besides, there is a continuous allocation of funds.

According to Jaharuddin, (2018), The steps for implementing cash waqf for education are: (I) Institutional, (2) education (massive socialization), (3) Collection of cash waqf and other types of waqf, (4) investment management, and (5) management of profit sharing. WhileSiswantoro \& Rosdiana, (2016)argues that cash waqf needs support from many aspects in order to maintain its sustainability. Knowledge creation and innovation from related aspects can strengthen the sustainable development of cash waqf in any form.

For this reason, this paper was written to achieve two research objectives: The first is to study the implementation of waqf in Malaysian IPT. The second isto study the exact variation of waqfthat can be applied to higher education. This study took the form of literacy, and data were collected from various literature reviews. This study develops a theory that can be applied to Malaysian higher education. The development and diversity of waqf instruments can be found in the following subtopics. 


\section{B. THEORETICAL}

\section{Development of Education Waqfin Malaysia}

The concept of waqf for developing public education is wellknown in this country(Ibrahim, Amir, \& Masron, 2013; Ismail et al., 2015; Sari, Yusof, \& Ibrahim, 2018)and the proof is the variety of teaching huts that sit like mushrooms in Malaysia's north, such as in Kedah, Pinang and the Perak islands, which mostly concentrate more on the low and middle levels of education(Johari et al., 20I4). Early education waqf in Malaysia manifested in various forms, such as scholarships, financial and student dormitory buildings,as well as learning tools, such as tables and books(A. Z. A. Latiff, Ismail, \& Daud, 2006). This development is important because this study found that funding education through waqfimplementation can reduce the problem of children dropping out and those who cannot continue their studies due to poverty(Mustaffa \& Muda, 20I4a).

Furthermore, the diligence of previous Islamic leaders in the practice of waqf worship continues to be nourished by present generations, and the proof is His Royal Highness the Acting King of Perak Darul Ridzuan, Raja Nazrin Shah, who gave a very meaningful decree on education waqf when officiating the ceremonies of the sixth convocation of the Sultan Azlan Shah Islamic University College on I9 December 2013(Ismail et al., 2015). Other sultans should follow this system, and with this, the system of government will be more blessed by Allah SWT. Also, the waqf in the form of a land grant to be used as a foundation for educational institutions is widely available in Malaysia, including, for example, in the state of Terengganu, at Sultan Zainal Abidin University (UniSZA). The university was established on the land of waqf contributions by certain parties(Kim, 1980). Besides, Terengganu's Culinary Academy, which is a vocational school, was also developed on waqf land managed by the Terengganu Islamic Religious and Customs Council (MAIDAM)(Ismail et al., 20I5). Most students enrolled in this institution receive education assistance and a subsidized allowance from Giat Mara. Apart from this, Terengganu also has private institutions of higher learning based on the waqf concept, i.e. University Bestari College (UCB) in Setiu, Terengganu. This institution was established by the Malaysian Orphanage Welfare Organization (PEYATIM). UCB has developed the concept of waqf in higher education and has provided greater opportunities for orphans and the poor in Malaysia over the past few years. 
In Kedah, educational institutions that have been developed on waqf land include Maktab Mahmud in Alor Setar(Kim, 1980). The Mahmud College has established as a collection of zakat and waqf by the people and local generosity. The entire waqf land is fully utilized to develop educational facilities and to generate financial resources for students to continue their studies in the Middle East (National Archives of Malaysia, 20I4). Also, the Darul Ulum Islamic College (KIDU) was also established through the collection of zakat and infaq as alms and waqf from the public(Ismail et al., 20I5). KIDU offers the opportunity to study at the low, middle and high levels of education.

The construction of student dormitory facilities from Johor for higher education concentrating on religion and medicine in several Egyptian and Jordan universities is one example of the efforts conducted by the Johor Islamic Religious Council to cultivate the waqf concept in the state's society. The state of Johor is also currently in the process of establishinga pre-university education centre, Madrasah Tahfiz Medik. The Johor Waqf Shares fully support the project's finance.

Also, the Melaka Islamic University College (KUIM), a fully-owned IPTS of the Melaka State Government, has taken the initiative to establish a charity waqf fund that was launched in 20I I(Ismon, Ramli, Dahalan, Romli, \& Hashim, 20I5). The waqf received by KUIM takes the form of cash. The collection of cash waqf is derived from public contributions and students and through a minimum deduction of RMIO from KUIM staff salary. However, cash waqf funds earned by the KUIM are still insufficient to build a permanent asset building that can be utilized by students, staff and the surrounding community.

The Islamic University of Malaysia (UIM), located in Selangor, is the first Islamic institution of higher learning in Malaysia established by the Malay Rulers and is fully engaged on the waqf platform of the public and corporate institutions(Ismail et al., 2015). In addition to UIM's establishment, another institution based on the waqf concept includes the Selangor International Islamic University College (KUIS). This institute was established by the Selangor Islamic Religious Council (MAIS) in I995. The collection of zakat and waqf by KUIS cooperate with the Selangor Zakat Board (LZS) and the Selangor Waqf Corporation (PWS). In addition, the development of waqf in higher education institutions is increasing with the involvement of IPTA, such as the International Islamic University Malaysia (IIUM), which established the IIUM Endowment 
Fund in 1999 (Website IIUM, 2015), the Universiti Kebangsaan Malaysia (UKM), with Waqf and UKM Endowment Fund in 2010 (UPM), with UPM's Knowledge Waqf Fund in 2012 (UPM's Website, 20I5) and at the Universiti Sains Islam Malaysia (USIM) in 20I3, with Dana Waqf Al-Abrar. Establishment of waqf funds at universities is generally intended to receive domestic and foreign financial assets, cash and shares to be used to fund scholarships, loans and expansion activities, such as investments(Mustaffa \& Muda, 20I4a).

The development of education waqf in the world is multiplying and creates positive developments every year. This progress indicates that society increasingly understands the importance of waqf for educational purposes. Even the importance of waqfinust be encouraged for the development of higher education waqf in this country. As a result, there are four determinants of the success of the implementation of waqf for education: community awareness, demographic conditions of high Islamic population, the stable economic position of Muslims and efficient and professional governance(Sunny, 2007). This possible method should be explored and optimized for its sustainability to benefit the entire Muslim community.

\section{Higher Education Waqf Issues}

Based on the development of waqf for education in Malaysia discussed previously, we can see that waqf can be used as an instrument for the funding and development of educational institutions both inside and outside of the country. The method of waqf is also applied due to the potential benefits for higher education in Malaysia.

Although waqf has the potential to be widely implemented in Malaysia's higher education, three issues have been identified that need to be discussed. First, high funding for IPT is crucial. This education aspect is an investment of human capital and requires a specific and sustainable source of funds to produce quality human capital through the provision of facilities and infrastructure or teaching staff at a school or IPT(Ali \& Wahid, 20I4). The need for alternative funds is required as the IPTSs must fully finance their operating expenses, Ismon, Ramli, Dahalan, Romli, \& Hashim, (2015), while the IPTAs receive only 70\% of the government's support(Hussin \& Rashid, 2015).

Additionally, the allocation for the development of this education sector is increasing from year to year, and this requires observations and other alternatives to 
reduce the burden of the government to provide adequate funding in the education sector. More productive cooperation can be achieved between the academy and the industry, particularly in the areas of research, development and commercialization. Budget constraints and higher education cost increases should also be addressed through the enhancement of productivity and effectiveness of the higher education system and IPT in line with the overall financial sustainability of the system (Education Development Plan Malaysia 2015-2025). The spending government in the year 2019 is increase $14.80 \%$ (RM7.76 billion) than previous year (Finance Ministry of Malaysia, 2019).

This positive rate indicates that the government's concern for providing adequate funding needed to cover the costs of developing the quality of higher education in the country is competitive both in state and abroad. Unfinished financial resources will also lead to various problems, such as a lack of sufficient provision of facilities, limited human resources and a lack of promotional activities that will lead to a poor understanding of the concept of education waqf. Therefore, financial management and funds are the main focuses of the success of waqf education institutions. The reason is that if there are no adequate and consistent funds, the waqf education institution will have difficulty operating properly (Mustaffa \& Muda, 20I4a).

The second issue is related to waqf legislation. The existence of constitutional and state law provisions in waqf matters is necessary to avoid questions about the use of the term 'waqf and to ensure it is acceptable to all levels of society. This is because most states in Malaysia do not define waqf in detail, excepting a few states, and most of the definitions provided in some of the enactments merely touch on general and special waqf properties of all types, including land categorized as immovable property(Hussin \& Rashid, 2015).

Also, several state waqf enactments have been enacted and created in order to facilitate the effectiveness of waqf management because there are many weaknesses in the provisions of the law relating to waqf. Although there has been drafting, the existing waqflaw is still inadequate to make the administration and management of waqf more effective and comprehensive(Hussin \& Rashid, 20I5). From the perspective of law enforcement, waqf must be supported by the rules and frameworks to guarantee the sustainability of the waqf institutions and to encourage the religious obligation of Muslims through waqf(Dahlan \& Mohamad, 2017). This is because there is a resolved hesitation within society about the 
benefit and purpose of education, mainly because the existing legislation does not adequately protect waqf property. Additionally, this is partly due to management inefficiency as there is no specific law to protect waqf for education purposes(Hussin \& Rashid, 2015).

The third issue is related to the waqf administration. The existence of administrative and management inconsistencies has created conflict in managing waqf property due to the unmodified waqf data and information. There is also a problem with the unstandardized structure organization division and administrative units(Hussin \& Rashid, 20I5). Furthermore, there is a shortage of experts and human resources, which often challenges the management of waqf property in Malaysia, i.e. MAIN, as the main body of waqf property administrators are burdened with such problems(Ismon et al., 2015), and, at the same time, the PLAN staff are charged with various other chores, resulting in a specialization attention deficiency in the development of waqf(Hussin \& Rashid, 20I5).

Also, this education waqf should be applied based on a concept that is not dependent on any government financial resources that are dominated by the political system (R. N. A. R. Ramli \& Hamid, 20I4). For example, the uniqueness of waqf in Turkey is that it is not associated with political or religious ideology but is based on mutual assistance and respect for fellow human beings. Nevertheless, if not dealt with thoroughly and professionally (Hassan \& Shahid, 2010)using a selfreliant welfare organization (Furqon, 20I2)and excellent and prudent management(Mustaffa \& Muda, 20I4a), there is uncertainty in the administration and sustainability of the education waqf funds, as well as a lack of achieving its objectives of becoming an economic generator and opening up new opportunities to meet the social needs of Muslims(R. N. A. R. Ramli \& Hamid, 20I4).

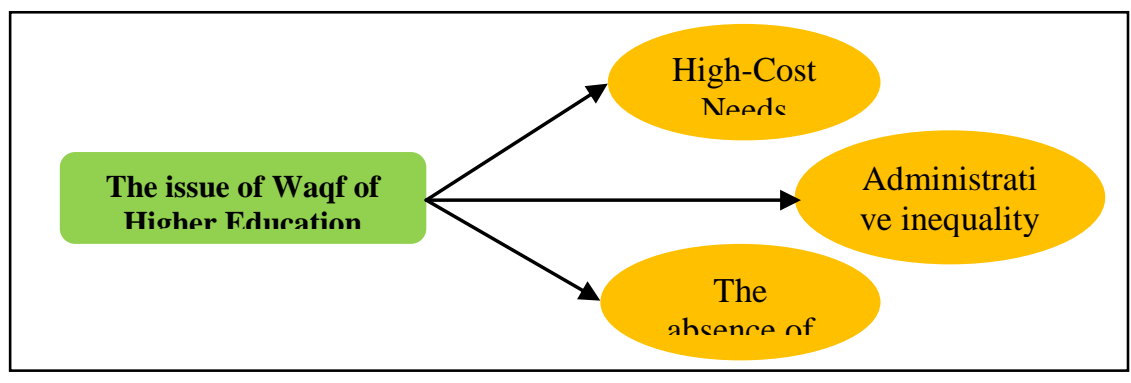

Figure I

Issues In Malaysia's Higher Education Waqf 
It is even more unfortunate if the university based on waqf has been successfully established but is unable to survive due to a governance problem that does not help resolve the consequences(Hussin \& Rashid, 2015). Failure to solve this problem could stop the education process, such as at al-Bukhari University, which is facing internal problems of university management(Hussin \& Rashid, 2015; Mustaffa \& Muda, 20I4a). A summary of the issues in higher education waqf can be seen in Figure I.

Based on Figure I, the identified issues will create a crucial situation because if the problems are not solved, then it is likely the university operations will need to be stopped. Therefore, researchers are encouraged to study and closely examine the application of the diversity of waqf instruments that can be applied to higher education in Malaysia.

\section{METHODOLOGY}

This study uses the documentation analysis method of social research. This analysis is used because it combines coding content into a theme, similar to focus groups or interview transcripts from various documents(Bowen, 2009).

\section{RESULTS AND DISCUSSION}

In this topic, several waqf instruments for higher education will be discussed. Among them are cash waqf, kaki waqf, irqod waqf, sukuk, waqf shares, corporate waqf and istibdal.

\section{Cash Waqf}

Waqf instruments, such as cash waqf, undeniably have excellent potential to develop the economy of Muslims, particularly in financing social and cultural activities, including the education sector. According to Abdul Khalim \& Zakaria, (20I4), the method of cash waqf not only keeps capital or assets but must provide multiple benefits and can generate new waqf properties in the form of permanent property.

In other words, Cizakca (1998) states that cash waqf is created by cash, and the results are used for profit purposes, with the aim of obtaining the pleasure of Allah SWT. Also, cash waqf also functions as a scheme that encourages people to contribute cash waqf at a minimum value. Furthermore, the accumulation of cash waqf funds will be consolidated as capital to purchase and transport 
permanentproperty, such as land and buildings(Aziz \& Johari, 20I4). In the context of Malaysia, the 77th Malaysia National Council for Religious Affairs Fatwa Committee convened on I0-I2 April 2007, in Kuala Terengganu, that waqf in cash is allowed in Islam. ${ }^{2}$ This is also supported by Abdul Khalim \& Zakaria, (20I4), who stated that Imam Az-Zuhri, a well-known scholar in hadith knowledge, has concluded that waqf in the form of dinar and dirham is mandatory for preaching, the welfare of the ummah and the education of Muslims. This issued fatwa is a manifestation of the recognition of immovable property, such as cash, as one of the forms of waqf assets that have been adopted in Malaysia.

The implementation of this cash waqf has evoked a public response due to several factors. According to Htay, Mohamed, \& Osman, (20I2), among the factors affecting the Muslim community, particularly in Malaysia, in making cashbased donations is that the waqf concept is a religion-promoted practice. It is understood in performing cash waqf that the trust is given to the waqf institution in administering waqf property, efficient management and environmental factors. Also, Mohammad, (2009)added that cash waqf has an attractiveness and liquidity, making it one of the choices in the waqf development project. Cash waqf is also very useful in mobilizing funds and investments using the foundation concept, such that it can play an essential role as a financial institution(Lahsasna, 20I0).

Practically, cash waqf is also seen as one of the alternatives that give waqf the potential for development among Muslims(Harun, Abd Mutalib, Rashid, Murat, \& Niy, 2016). The physical form of cash waqf makes this method easier to manage and can be used as a tool to generate and expand waqf to the maximum level. The application of this cash waqf can be seen as one of the means of financing for developments such as business premises or other infrastructure that benefits the community. Some scholars, such as Mahamood, Ab Rahman, \& Ahmad, Hasnol Zam Zam Muhammad, (2007), have stated that the contribution of this cash waqf could be managed by the government, society, PLANTS and corporate bodies, such as Corporate Social Responsibility (CSR).

Based on the educational aspect, this cash-generating method is used as education development, construction of accommodation infrastructure or student dormitories, subsidies for educational management, sukuk issuance and inter-agency collaboration for education purposes (Ahmad, Muhammad, \& Kamaruzzaman, 
20I2). Cash waqf also demonstrates an effective mechanism in developing Islamic educational institutions. The cash waqf system has proved the effectiveness of its essential role in universities such as Al-Azhar University. The same situation can be seen in Malaysian learning institutions based on the implementation of waqf. Research institutions that have applied the cash waqf method include the Darul Ulum Islamic University (KIDU)(Aziz \& Johari, 20I4). This demonstrates the effectiveness of the cash waqf concept to play an important role in a university such as Al-Azhar, and the same situation can be seen in Malaysian institutions of education, which are growing based on the implementation of waqf. Among the institutions that have implemented the cash-bearing method is the Darul Ulum Islamic College (KIDU), which is established through the collection of zakat and infaq, such as alms and waqf from the public(Ismail et al., 2015). Among other institutions of study are UIAM, UKM, UPM, UTM, USIM and USM. According to Mustaffa \& Muda, (20I4), the implementation of cash waqf at the university will be utilized to fund scholarships, loans and expansion activities, such as investments and other educational activities. The issue has shown that cash waqf implementation is significant as the study found that funding education through waqf instruments could reduce the problem of dropout and the absence of children who cannot continue their studies due to poverty(Mustaffa \& Muda, 20I4a; Salleh, 2017).

Hence, the concept and method of cash waqf should be expanded widely, and now the higher education sector in Malaysia should take the best possible advantage in making this cash waqf one of the alternatives for reducing the burden borne by institutions, particularly in education financing.

\section{Irsyad Waqf}

One implementation that can be featured for a higher education waqf source is irsyadwaqf. Irsyadwaqf may also be interpreted as land that the government considers for public benefit purposes, such as schools and hospitals. The term 'itsyadwaqf can be seen in some states' enactments. According to Mahamood et al., (2007), this term is derived from two Arabic words, 'waqf and 'irsad, which, when combined, become "waqfal-irsad, which refers to the property of the rulers of the government as well as certain bodies or organizations. The term "itsyadwaqf can be seen in some of the state enactments. Among these, such as in the Selangor Enactment under Section 9 (2) (a) of the Muslim Waqf (Selangor) I999 (No. 7 of 1999) Enactment, in which it is interpreted as 'a land which has been imposed 
by any corporation, another body according to Islamic law'. Meanwhile, the Melaka Enactment under the Waqf Enactment (State of Malacca) 2005 (No. 5 of 2005) also makes its interpretation as 'waqf from Baitulmal land, government land or land of any corporation, institution, body or other bodies of law according to Islamic law'. At the same time, the Waqf Land Management Manual Waqf Zakat and Hajj Department 2006 defines 'irsyadwaqf as 'the submission of any land as waqf by any state authority, federal government or any corporation, institution, organization or other bodies according to Syariah laws'.

In other words, irsyadwaqf is not from personal/private ownership but is a gift from the government, i.e. the land gazette for the site of mosques, religious schools, Islamic welfare homes, cemeteries and so on. Mahamood et al., (2007)also mentioned that the irsyadwaqf is focused on the rulers' acting on the property of Baitulmal, including the movable and immovable property in it and its application to the construction of mosques, educational institutions, hospitals and so on, which are fundamental to the general issues (maslahah 'ummah). Hence, expansion of the itsyadwaqf method can be extended not only for religious institutions but also to commercial, health and recreation centers created based on Islamic law, as well as to support the governments and other Islamic agencies for earning high profits in business.

\section{Shares Waqf}

The shares waqf is a new form of waqf system that offers a scheme to encourage participants to buy shares at a certain price, e.g. RMIO per unit. Furthermore, some state enactments have defined the term shares waqf. Among them, Section I7 (I), the Waqf (Selangor State) Enactment 1999 provides for shares waqf as a council to offer shares of waqf against any property acquired or to be acquired and subsequently charged to the Council. Section I7 (2) of the same enactment further states that the shares waqf are regarded as general waqf, rather than particular waqf. For the Waqf (Negeri Sembilan) Enactment 2005, his shares waqf were offered as part of the waqf scheme under Section II (I). Under Section II (2), the scheme begins with a share purchase offer by the Negeri Sembilan Islamic Religious Council (MAINS), and the buyer of waqf will then hand it over to MAINS as waqf. Section II (3) stipulates that the waqf stock that was formed would be not only a general waqf but also a particular waqf. In Johor, Section 2 The Waqf Rules 1983 provides for the shares waqf to establish a Waqf Musytarik through shares that are subject to waqf or later on. In addition, according to the 
Department of Islamic Development Malaysia (2009), the fourth National Fatwa Committee for the 4th Malaysian Islamic Religious Affairs Meeting convened on I3-I4 April 1982, in Kuala Lumpur had concluded that holding a wholly owned shares waqf with business companies through share purchase then being charged with the purpose of developing the property of waqf is required according to the terms of waqf.

Based on the definition of waqf described earlier, it can be understood that the concept of shares waqf centers on the perspective of its scheme. MAIN acts as a trustee and will be initiated with cash waqf based on the issue value of one unit of shares offered and, subsequently, involves the conversion process with the purchase of assets or their application to the development of a planned project under MAIN(Abdul Khalim \& Zakaria, 20I4).Benefits in the form of waqf stock dividends can also be applied to meet the financial requirements and to strengthen Islamic institutions of higher learning, and the results of the collected shares waqf can be used for infrastructure development (CAPEX) expenses, such as building institutional mosques, libraries, student dormitories or other academic buildings(Bahari \& Ahmad Shukor, 2017).Also, the research by the current development of the country in the matter of waqf is found to have had the PLAN, which has begun introducing waqf practices from this category of funds, such as in Selangor, Johor, Melaka and Pahang, via shares waqf. Among them, the Selangor Islamic Religious Council (MAIS) also offered Selangor shares waqf to Muslims in cash by buying the share units offered and realizing it with the purpose and importance of Muslims to cultivate and educate the spirit of cooperation among Muslims, which will mobilize the social and economic community of Muslims (MAIS, 20I2)(Mahamood et al., 2007).

In addition to Selangor's participation, Johor is also involved in the issuance of shares waqf. The Johor shares waqf is a scheme in which the Muslim community will buy a share of RMIO.00 per unit from the Johor Islamic Religious Council (MAINJ) and subsequently disburse the shares to the Religious Council Islamic State of Johor. Consequently with the purpose of benefit, it will be distributed to five divisions, namely religious school waqf, waqf al-Quran, waqf dormitory in Egypt, waqf shop building in Nusajaya and waqf oil palm plantation(Abdul Khalim \& Zakaria, 20I4). Also, there is participation from Yayasan Islam Malaysia Foundation (YADIM). YADIM offers its shares of waqf, including the former Yayasan Pembangunan Ekonomi Malaysia (YPEIM), which introduced the 
National Waqf Development Scheme to promote the culture of jariah practices among Malaysians(Mahamood et al., 2007).

Hence, shares waqf are promoted by the community with the purpose of helping Muslims, particularly in providing funds for educational purposes and carrying out waqf methods. Such a method will hopefully influence more Muslims to engage in the practice of waqf and further enhance the socio-economic development of Muslims without involving permanent properties.

\section{Corporate Waqf}

Awareness of developing waqf property has grown in most Islamic countries through corporate waqf instruments. This corporate waqf refers to the management of waqf properties in the form of movable property, such as cash, company shares and stock dividends, fully administered by corporate entities or in collaboration between corporate and waqf authorities(Mohsin, 2013). Besides, among the critical elements of the organizational waqf structure, waqf assets are in the form of movable property, while the waqf trustee, a corporate company, is mutually the beneficiary of waqf(A. M. Ramli \& Jalil, 2013). The tendency of corporate companies to engage in the aspect of management and development of waqf assets indirectly demonstrates the commendable ethics of the corporate world, which not only focuses on profit-oriented activities but even on companies. It is also involved in waqf programs, such as education, health and property management waqf (A. M. Ramli \& Jalil, 20I3). Also, there are corporate companies in several countries that are involved in the management of waqf property, particularly those involving the education and health sectors. Among them is Turkey, where the two largest corporate companies, through the Koc Foundation and Sabanci Foundation, have been directly involved in financing the establishment of a university and a waqf school(Çizakça, 20II). While in Pakistan, there are corporate companies through foundations, such as the Hamdard Foundation, managing and attributingwaqf funds to recipients consisting of schoolchildren and the poor(A. M. Ramli \& Jalil, 20I3, 20I4).

In Malaysia, there is a development of waqf through the involvement of corporate companies. Among them is the Johor Corporation (Jcorp) through Waqf An-Nur Korporat Sdn. Bhd. (WANCorp). It is involved in the development of waqf through its main contribution to company shares, and this makes it internationally unique(Khairi et al., 20I4). Among the programs undertaken by WANCorp in terms of education and human capital, developments include the 
sponsorship of programs at the IPT level, such as student conventions, contributions to student associations and student life development like SMART prayers, schooling aid and more(Mustaffa \& Muda, 20I4a). Also, WanCorp declared that all of its income earned as dividends would be distributed according to formula 70:25:5. A total of 70\% benefits were returned to WANCorp for reinvestment and human capital development, 25\% were returned to WANCorp for fisabilillah and 5\% to the Johor Islamic Religious Council(Khairi et al., 20I4). The more significant percentage of reinvested capital is due to the primary longterm goal. It aims to capture expanded corporations with strategic national business, while also empowering the Muslim economy(Mujani, Taib, \& Yaakub, 20I4).

Also, there is participation Supply Chain Management (SCM) from financial institutions cooperating(Anggraini, Hamiza, Doktoralina, \& Anah, 2018; Arafah \& Nugroho, 2016)with MAIN to empower the waqf institution. Among them is the Bank Muamalat Malaysia Berhad (BMMB), which partnered with the Selangor Waqf Corporation to introduce a cash waqf scheme known as Waqf Selangor Muamalat. The results will then be distributed to several sectors, including for educational purposes to build school buildings, the contribution of educational equipment such as the Quran, reference books to religious schools and Mahad tahfiz, as well as primary equipment donations to schools, such as toilets, surau and classes(Talib, Ismail, \& Azizan, 20I4). Also, there are several other strategic partnerships, including, for example, between the GiatMara, the Malay Religious and Indigenous Malay Council (MAIDAM) and Yayasan Waqf Malaysia (YWM) for the construction of the Terengganu Kulinari Academy(Ahmad et al., 20I2). Funding for the academy, which costs RM 2.5 million, is provided by YWM, and GiatMara provides the learning syllabus. The conclusion of academic development and operations is shown in Figure 2. 


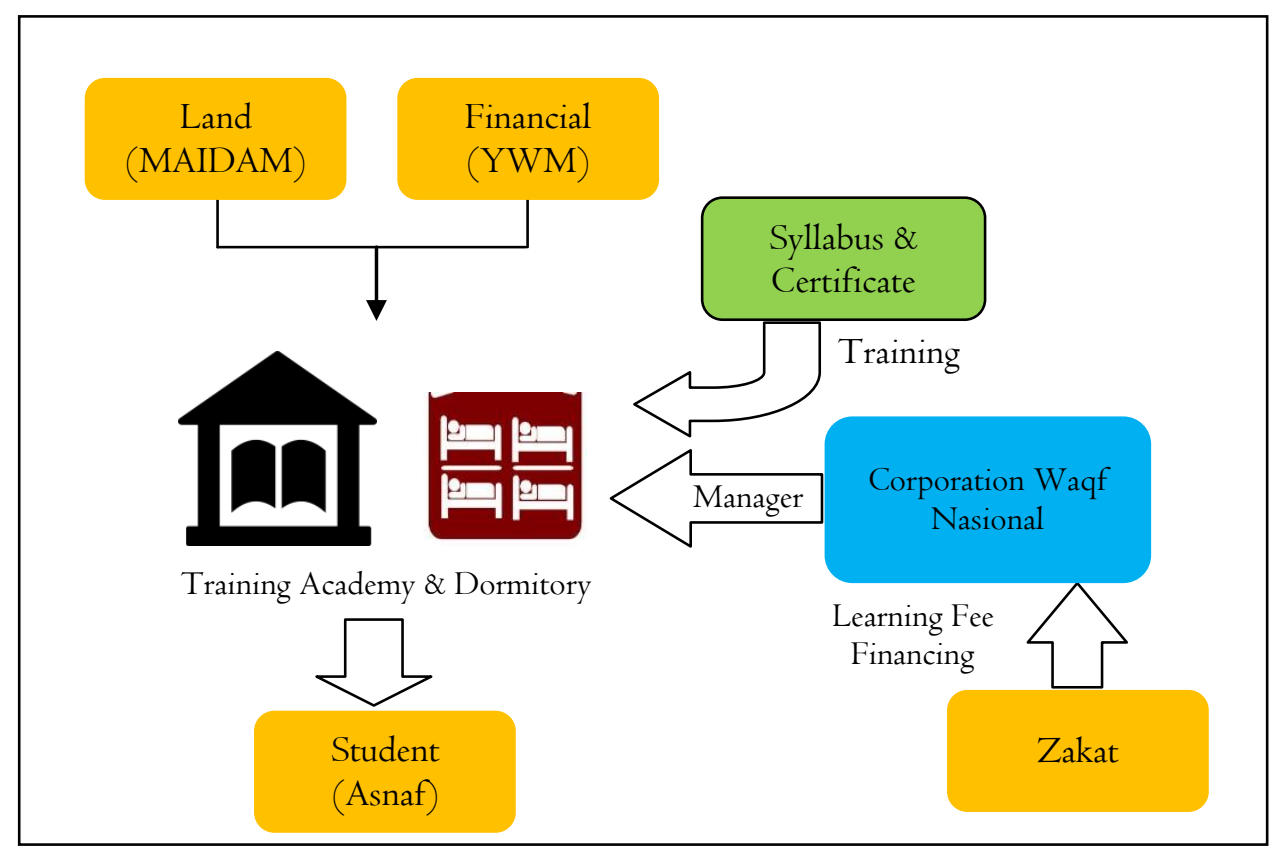

Figure 2

Development and Operation of the Terengganu Culinary Academy

However, the exploration of funding sources for the development of waqf in financing higher education through a more innovative approach should be intensified. This is to increase the development of waqf in Malaysia, particularly among corporate bodies, in carrying out social responsibility for the community[10,39]. Therefore, three ways have been proposed for increasing the company's endowments for the development of IPTs(Ismon et al., 2015).First, the IPTs will be established as a corporate institution that acts as mutawwali to manage the waqf funds. Second, the welfare fund of IPTs should have strategic land for future development purposes. Third, alumni of IPTs should be involved in the waqf IPTs to contribute continuously to the institutions. The government should also provide various incentives to attract more engagement among community members as well as corporate bodies contributing funds through the waqf concept for higher education funding, including, for example, the exclusion of incentives taxes for companies that are directly involved in corporate waqf practices, as is done in zakat practices(Ali \& Wahid, 20I4; Bahari \& Ahmad Shukor, 2017; Doktoralina, Bahari, Herliansyah, Ismail, \& Putri, 2018). 
Hence, the involvement of these corporations can assist the IPTs in diversifying the funding of waqf resources as well as in the development of infrastructure facilities for higher education waqf.

\section{Istibdal}

The istibdal method can be used to diversify the technique in the development of waqf land. The term 'istibdal may be defined as buying another property with the proceeds of a sale to be used as mawquf to replace the property sold, covering any property acquired by way of substitution with the same property or a better property of its value and benefits (JAWHAR, 20I0). The term is taken from the word 'ibdal, which has the purpose of issuing the property that is taken from the original terms of the carry out of waqf to be converted to another property in which the second property will be the waqf to replace the first(Mahamood et al., 2007). Also, there are enactments from several states that have defined the term 'istibdal. Among them is the Waqf Enactment (State of Malacca) 2005 (No. 5 of 2005), which defines 'istibdal as replacing a waqf property with another property of the same or higher value of money, either by substitutions, exchanges, sales or any other ways according to Islamic law. Section 2, the Waqf Enactment (State of Selangor) also has a corresponding interpretation, in which only the 'exchange' statement is omitted. The Waqf (Negeri Sembilan) Enactment 2005 provided the "istibdal term as similar to the Malacca Enactment, with the substitution of mawquf with other property or money equal to or greater than the mawquf, either by substitution, buying, selling or any other means following sharia principles.

Also, the application of the istibdal method for education development purposes can be referred to in Singapore. The WARESS has rebuilt the waqf of Madrasah al-Maarif al-Islamiah Singapore through the istibdal concept by transferring the madrasah from the land of waqf by developing a better eight-store religious school with complete and processed facilities. It replaced the previous facility in considerations with the need to have a better learning atmosphere and hostel facilities(A. Latiff, Zaki, Ramli, Ismail, \& Sulaiman, 2006).Nevertheless, the Singapore Fatwa Council allowed the istibdal process based on four matters. First, the assets are in an abandoned state. Second, the assets are in danger of being taken over(Karim, 2010). Third, the assets are in an inappropriate location. Fourth, the assets will provide a better return when replaced and developed. 
Another example that can be highlighted for educational purposes is that of the istibdal case in Penang. The Penang State Government has given a piece of land to the Penang Islamic Religious Council (MAIPP) for the construction of Maahad Al-Mashoor Al-Islami in Balik Pulau, Penang. It is to replace the actual site that has been taken over for the construction of KOMTAR building for administrative purposes and the main business of the state(Ahmad et al., 2012). The agreement is between MAIPP and the state government, and the state government has allocated RM6 million and 3I acres of land compensation in the Balik Pulau district as a landlord (istibdal), and the maahad development costs RM 42 million to be built(Hisham, Jaseran, \& Jusoff, 2013). Therefore, although the use of the istibdal method for education development is still not very popular, it provides opportunities for exploration and expansion. The aim is to avoid unproductive land of waqf, while also seeking the pleasure of Allah SWT (Mardhatillah). The potential of this method should be explored and detailed to avoid confusion that may arise within society. The summary of the diversity can be seen in Figure 3.

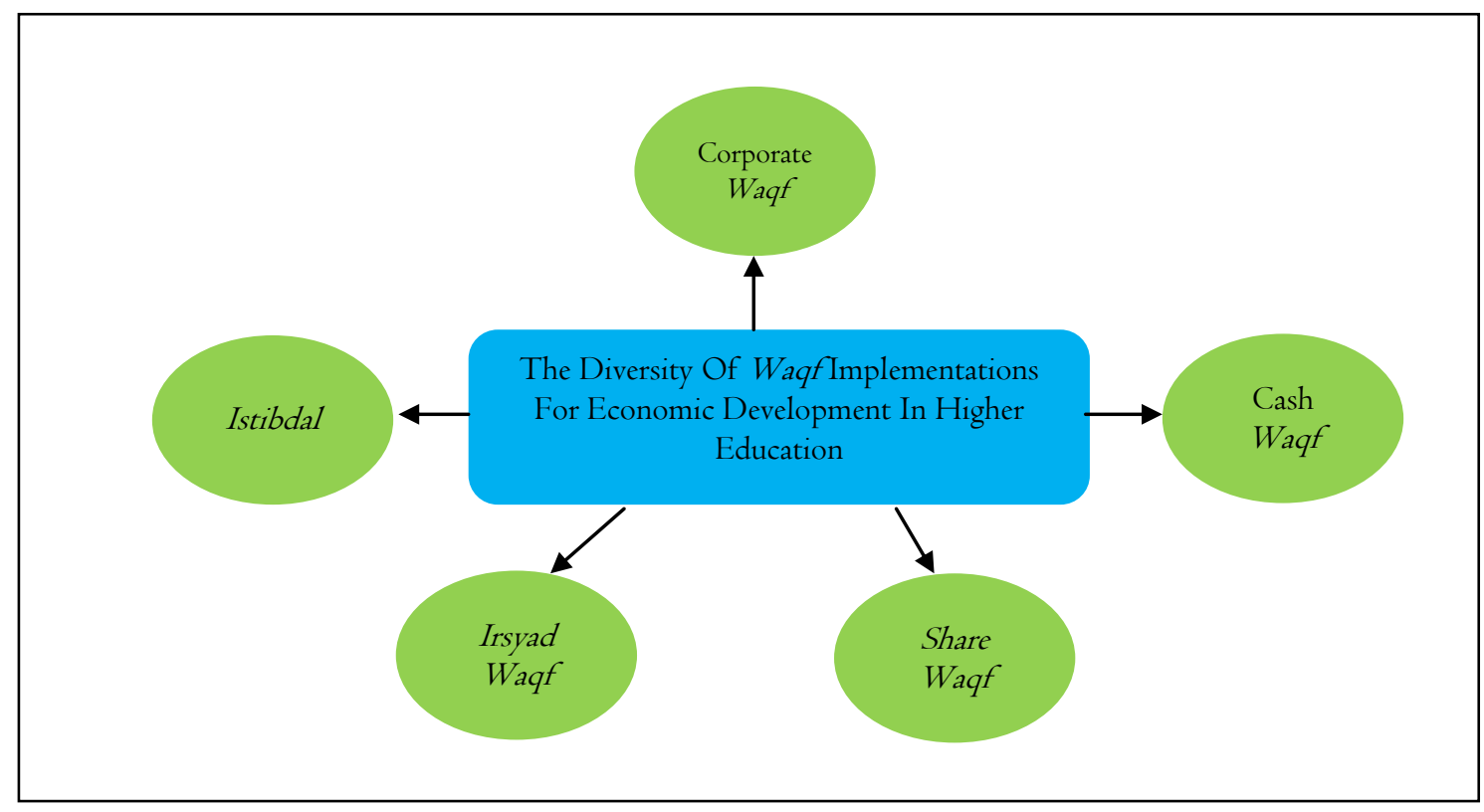

Figure 3

The Diversity of Waqf Implementations for Economic Development in Higher Education 


\section{E. CONCLUSION}

In general, the waqf implementations is one of the alternatives to increase the economy of the people and can be used for higher education in Malaysia. The development of higher education waqf in Malaysia is growing as the diversity of waqf implementations can be used efficiently and optimally. Based on the completed research, the findings implicated in the theoretical facet of this study can also be used as the basis for further research to develop knowledge related to the Malaysian higher education waqf. It is also expected to benefit in finding the best method of application of waqf for IPTA and IPTS in particular, and can also be used as a reference source for relevant agencies and the community. Also, there is an urgent need to have a paradigm shift while maintaining close cooperation between the various parties to realize the potential of waqf as a driving force for socioeconomic growth and higher education in Malaysia. Nevertheless, a comprehensive strategy must be implemented to produce a more productive and dynamic waqf so that the dependence of the IPTAs on funds donated by the central government can be reduced without affecting the ability the IPTAs to continue producing future leaders. However, this study is still exploratory and experimental, and thus, there is still much research space available to strengthen and develop education waqf as a primary source for the education and development of the Muslim community.

\section{Acknowledgment}

We wish to thank Professor Dr Muhammad Syukri Saleh and the External Reviewer. We also express our appreciation to the team of the Center for Islamic Development ManagementStudies (ISDEV) of Universiti Sains Malaysia and to all of the Ikatan AhliEkonomi Islam team of Indonesia Komisariat Universitas Mercu Buana, The economics and business faculty of the Universitas Mercu Buana which havebeen very constructive in the various stages of the development of this article.

\section{REFERENCES}

Abdul Khalim, M., \& Zakaria, N. H. (20I4). Peranan Media Massa Dalam Mempromosikan Saham Wakaf Johor. Pengurusan Jawhar, 8(I), I-I66. http://doi.org/http://dx.doi.org/I0.19I93/0393-6384_20I6_I_3I

Ahmad, A., Muhammad, S. bin, \& Kamaruzzaman, M. A. bin. (2012). Education development through waqf. In 3rd International Conference on Islam and 
Higher Education (Vol. I3, pp. I-22).

Ali, S. Z., \& Wahid, H. (20I4). Peranan dan kepentingan dana wakaf institusi pendidikan tinggi di Malaysia. Kertas kerja Persidangan Kebangsaan Ekonomi Malaysia ke-9 (PERKEM ke-9). Kuala Terengganu, Terengganu, Malaysia. Anggraini, D., Hamiza, A., Doktoralina, C. M., \& Anah, S. (2018). Application of Supply Chain Management Practices in Banks : Evidence from Indonesia. International Journal of Supply Chain Management, 7(5), 4I8-427.

Arafah, W., \& Nugroho, L. (2016). Maqhashid sharia in clean water financing business model at Islamic bank. International Journal of Business and Management Invention, 5(2), 22-32.

Aziz, M. R. A., \& Johari, F. (20I4). Waqf: Financing for Higher Education: Issues, Challenges and the Way Forward. USIM Publisher.

Bahari, Z. \&, \& Ahmad Shukor, A. S. A. (20I7). Pemerkasaan tadbir urus wakaf pendidikan tinggi malaysia (pp. 28-44).

Bowen, G. A. (2009). Document Analysis as a Qualitative Research Method. Qualitative Research Journal, 9(2), 27-40. http://doi.org/I0.33I6/QRJ0902027

Cizakca, M. (1998). Awqaf in history and its implications for modern Islamic economies. Islamic Economic Studies, 6(I).

Çizakça, M. (20I I). Islamic capitalism and finance: Origins, evolution and the future. Edward Elgar Publishing.

Dahlan, S. M., \& Mohamad, N. A. (2017). Waqf Literatures from Malaysia: 60 Years After Independence. In Global Waqf Conference. Pekanbaru, Indonesia.

Doktoralina, C. M., Bahari, Z., Herliansyah, Y., Ismail, N. A., \& Putri, P. P. (2018). Role of Accounting Zakat as a Support Function in Supply Chain Management: A Resurrection of the Islamic Economy. Int. J Sup. Chain. Mgt Vol, 75), 336.

Fazial, F., \& Bahari, Z. (2018). Problems Faced By the Pondok Institutions in Funding Development. International Journal of Academic Research in Business and Social Sciences, 8(6), I3I3-I320. http://doi.org/I0.6007/IJARBSS/v8-i6/4536

Furqon, A. (2012). Wakaf Sebagai Solusi Permasalahan Dunia Pendidikan di Indonesia. Dalam Jurnal Hukum Islam, IO( I), 35-52.

Harun, R., Abd Mutalib, H., Rashid, R., Murat, A., \& Niy, N. (20I6). Promotion as a Determinants for Waqf Awareness Among University. International 
Academic Research Journal of Social Science, 2, 95-99.

Hassan, A., \& Shahid, M. A. (2010). Management and development of the awqaf assets. In Proceedings from the Seventh International Conference--The Tawhidi Epistemology: Zakat and Waqf Economy, Bangi (pp. 309-328).

Hisham, S., Jaseran, H. A., \& Jusoff, K. (2013). Substitution of Waqf Properties (Istibdal) in Malaysia: Statutory Provisions and Implementations. Middle-East Journal of Scientific Research, I3(I3), 23-27.

Htay, S. N. N., Mohamed, M. O., \& Osman, A. F. (2012). Determinants of cash waqf giving in Malaysia: survey of selected works.

Hussin, R., \& Rashid, R. A. (2015). Isu-isu berkaitan tanah wakaf halangan kepada pembangunan institusi wakaf pendidikan tinggi di Malaysia. Malaysia.

Ibrahim, H., Amir, A., \& Masron, T. A. (20I3). Cash waqf: An innovative instrument for economic development. International Review of Social Sciences and Humanities, 6(I), I-7.

Ismail, M. H., dan Muamalah, F. P., bin Muhammad Som, H., Islam, A., Deni, M. I. M., \& binti Sulaiman, M. (2015). Model operasi wakaf pendidikan di malaysia. In International Conference on Cash Waqf 2015 (ICCW20I5) ( $\mathrm{p}$. 2I7).

Ismon, N. Y., Ramli, R., Dahalan, N. F., Romli, S., \& Hashim, R. (2015). Mekanisme wakaf sebagai instrumen pendidikan tinggi swasta: prospek dan cabaran Kolej Universiti Islam Melaka sebagai IPTS. Malaysia.

Jaharuddin. (2018). Potensi Wakaf Uang Pendidikan (Studi Kasus FEB UMJ). Ikraith-Humaniora, 2(2), 84-94.

Johari, F., Mohd Orip, N. M., Ab Aziz, M. R., Abu Hussin, F., Ibrahim, P., Abd Wahab, K., ... others. (20I4). Intention To Donate Cash Waqf Repeatedly: A Preliminary Descriptive Analysis.

Karim, S. B. A. (20I0). Contemporary shari' a compliance structuring for the development and management of waqf assets in Singapore. Kyoto Bulletin of Islamic Area Studies, 3(2), I43-I64.

Khairi, K. F., Aziz, M., Laili, N., Nooh, M., Sabri, H., Basah, A., \& Yazis, M. (20I4). Human and economic development through share waqf (waqf corporate): The case of GLCS in Malaysia.

Kim, K. K. (1980). Perkembangan Pelajaran Agama Islam. Pendidikan Ke Arah Perpaduan: Sebuah Perspective Sejarah, ed., Awang Had Salleh, Kuala Lumpur: Fajar Bakti. Kuala Lumpur, Malaysia: Awang Had Salleh. 
Lahsasna, A. (2010). The Role of Cash Waqf in Financing Micro and Medium Size Eterprises (MMES). In Seventh International Conference--The Tawhidi Epistemology: Zakat and Waqf Economy (pp. 97-I 18).

Latiff, A. Z. A., Ismail, C. Z., \& Daud, N. M. (2006). Pengurusan harta wakaf dan potensinya ke arah kemajuan pendidikan umat Islam di Malaysia. Konvensyen Wakaf Kebangsaan. Hotel Legend, Kuala Lumpur, I2-I4 September 2006.

Latiff, A., Zaki, A., Ramli, A. H., Ismail, C. Z., \& Sulaiman, K. (2006). Pengurusan harta wakaf dan potensinya ke arah kemajuan pendidikan umat islam di Malaysia/Dr. Hj. Ahmad Zaki Hj. Abd Latiff, Prof. Madya Hj. Abdul Halim Ramli, Che Zuina Ismail, Kamarulzaman Sulaiman, Norzaidi Mohd. Daud. Malaysia: Institute of Research, Development and Commercialization.

Mahamood, S. M., Ab Rahman, A., \& Ahmad, Hasnol Zam Zam Muhammad, S. (2007). Konsep Wakaf Sebagai Instrumen Pembangunan Hartanah Di Wilayah Pembangunan Iskandar (WPI). Jurnal Pengurusan (Vol. I).

Mohammad, M. T. T. H. (2009). Alternative development financing instruments for waqf properties. Malaysian Journal of Real Estate, 4(2), 45-59.

Mohsin, M. I. A. (2013). Corporate waqf and its role in the different societies. In 2nd International Conference on Islamic Economics and Economies of the OIC Countries (ICIE 20I3). Prince Hotel \& Residence-Kuala Lumpur, 29-30 January 2013.

Mujani, W. K., Taib, M. S. M., \& Yaakub, N. I. (20I4). Educational Waqf (Islamic Endowment) in Malaysia. In Lecture Notes in Management Science 20I4-2nd International Conference in Humanities, Social Sciences and Global Business Management (ISSGBM 20I4) (pp. I I7-I20).

Mustaffa, N., \& Muda, M. Z. (20I4a). Management of Waqf Education in Higher Education Institution in Malaysia: A Literature Review. International Journal of Islamic and Civilizational Studies, $I(\mathrm{I})$.

Mustaffa, N., \& Muda, M. Z. (20I4b). Pengurusan wakaf pendidikan di institusi pengajian tinggi Malaysia: satu sorotan literatur. IJMS, 2I(2), 63-8I.

Ramadhan, A., \& Al, S. (2019). The Role of The Islamic Economy in Rationalizing Consumer Behavior. Journal of Islamic Business \& Economic Review, 2(I), I3-I7. Retrieved from http://jiber.stebilampung.ac.id Ramli, A. M., \& Jalil, A. (2013). Corporate Waqf Model and Its Distinctive Features: The Future of Islamic Philanthropy. In World Universities Islamic Philanthropy Conference. Menara Bank Islam, Kuala Lumpur, Malaysia. 
Ramli, A. M., \& Jalil, A. (20I4). Model Perbankan Wakaf Korporat: Analisis Wakaf Selangor Muamalat. Jurnal Pengurusan (UKM Journal of Management), 42.

Ramli, R. N. A. R., \& Hamid, N. A. (20I4). Kelestarian wakaf dalam membangunkan institusi pendidikan: Kajian awal. In Kertas Kerja International Conference on Postgraduate Research di Kuala Lumpur.

Ruthven, M. (2012). Islam: A very short introduction. OUP Oxford.

Salleh, M. S. (2017). Contemporary Vision of Poverty and Islamic Strategy for Poverty Alleviation. SAGE Open, 7(2). http://doi.org/I0.I I77/2I582440I7697I53

Sari, M. D., Yusof, A. A., \& Ibrahim, A. (2018). Sinergi Wakaf dan Keusahawanan di University College Bestari. Jurnal Syariah, 26 (I), 4I-70.

Siswantoro, D., \& Dewi, M. K. (2007). The Effectiveness of Waqf Fund Raising Through Mutual Fund in Indonesia. Singapore International Waqf Conference 2007, 243-268.

Siswantoro, D., \& Rosdiana, H. (2016). Sains Humanika Sustainability of Cash Waqf Development in Indonesia: A Quintuple Helix. Sains Humanika, 8(I2), III-II6.

Sofyani, H., Ulum, I., Syam, D., \& Wahjuni, S. (2012). Islamic social reporting index sebagai model pengukuran kinerja sosial perbankan syariah (studi komparasi Indonesia dan Malaysia). Jurnal Dinamika Akuntansi, 4(I).

Sunny, A. H. (2007). Dana wakaf untuk pendidikan: satu tinjauan awal. Jurnal Pengurusan JAWHAR, I(2).

Talib, H., Ismail, N., \& Azizan, N. I. (20I4). Pembangunan dana wakaf: kajian di Perbadanan Wakaf Selangor. In Proceeding of the International Conference on Masjid, Zakat and Waqf (IMAF 20I4) (pp. I05-I I4). Kuala Lumpur, Malaysia. 